\title{
Identifikácia aplikovanej morálnej filozofie akcentujúcej úvahy ekologického typu - ekologická etika.
}

\section{Lubov Vladyková}

Envigogika 11 (1) - Recenzované články/ Reviewed articles

Published/ Publikováno 9. 5. 2016

DOI: $10.14712 / 18023061.512$

\begin{abstract}
Abstrakt
Vychádzame z predpokladu, že práve $v$ ekologickej etike prekonávame bariéry medzi "dvoma kultúrami" tým, že teoretici z obidvoch kultúr vzájomne komunikujú, hladajú spoločný jazyk. Táto štúdia sa prikláňa $k$ ( $v$ súlade $s$ pragmatickým požiadavkom nájst' fungujúce riešenie problémov životného prostredia, alebo inými slovami interdisciplinárne nazeranie) ku kontextuálnemu a situačnému rozmeru etickej integrácie a rozhodovania $v$ problematickej oblasti eko-etického výskumu a riadenia. Etická integrácia nie je len teoretická alebo intelektuálna činnost' (tzn. filozofická asimilácia rôznych hodnôt, povinností a záujmov), ale je tiež forma praktického uvažovania, ktoré je často realizované protikladnými morálnymi činitel'mi v komplexných a často empiricky a morálne dvojznačných situáciach. Predpokladáme, že najdôležitejšie integrujúce úlohy $v$ každom rozumnom modeli etické analýzy musia mat́ metodický charakter: zvýšenie citlivosti jednotlivca voči etickému kontextu praxe (jeho chápanie príslušných morálnych princípov týkajúcich sa praxe) a podpora zlepšenia predstavivosti a analytickej zručnosti jednotlivcov tak, že sa stanú schopnými zlepšit́ úvahy o morálno-ekologických a environmentálnych problémov a ich riešeniach kreatívnym a systematickým spôsobom.
\end{abstract}

\section{KI'účové slová}

Ekologická etika, etika, ekologické vedy

\begin{abstract}
Working on the assumption that it is in the nature of ecological ethics to overcome the barriers between the "two cultures" by theorists from both cultures communicating with each other, seeking a common language. The present study is inclined to (in accordance with the pragmatic requirement to find a functioning solution to environmental problems, or in other words, the interdisciplinary vision) attend to the contextual and situational dimension of ethical integration and decision-making in the problematic of eco-ethics research and management. Ethical integration is not just a theoretical or intellectual activity (i.e. a philosophical assimilation of different values, responsibilities and interests) but it is also a form of practical reasoning, which is often realized by contradictory moral agents in complex and often empirically and morally ambiguous situations. We assume that the most important integrating role in every reasonable model of ethical analysis must focus on our actions and must have a methodological nature: an increase in the sensibility of the
\end{abstract}


individual towards the ethical context of practice (his understanding of the relevant moral principles concerning practice) and support the development of individual's imagination and analytical skills, to enhance his capacity to reflect on moral ecological and environmental problems and address them in a more creative and systematic way.

\section{Key words}

Ecology ethics, ethics, ecology science 


\section{Predbežné úvahy}

Ohlásená téma zastrešuje masívny korpus reflexií a konceptov, preto sa pokúsime načrtnút' a lokalizovat' len jednu z jeho oblastí. Ide o oblast' vzt'ahu a väzieb vedy (ekologických vied) a etiky, ktoré sú vo sfére ekologickej etiky nanajvýš aktuálne. Aj ked' existujú dôvody na skepticizmus vo vzt́ahu k spôsobu, akým ekologickí filozofi a ekologickí etici využívajú ekológiu na zdôvodnenie svojich koncepcií, nedomnievame sa, že optika ekologickej morálnej filozofie je inherentne nasmerovaná nesprávne. Vychádzame z predpokladu, že práve v ekologickej filozofii a etike prekonávame bariéry medzi „dvoma kulturami" tým, že teoretici z obidvoch kultúr vzájomne komunikujú, hladajú spoločný jazyk. Pri tomto hladaní sa „pravdy” vo filozofii rekombinujú s novými ideami, ktoré vyplývajú z experimentálneho bádania a prírodovedci stále viac menia svoje výskumné zamerania. Ciel'om tejto štúdie je náčrt hlavných línií argumentácie a poskytnutie určitého kauzálneho rámca, ktorý môže slúžit' ako vysvetlenie. Sledujeme dva okruhy skúmanej problematiky: 1. stručnú identifikáciu aplikovanej morálnej filozofie akcentujúcej úvahy ekologického typu, tzn. ekologickej etiky; 2. význam ekologických vied pri identifikácii, chápaní a riešení ekologického problému.

\section{Identifikácia základného pojmu: ekologická etika}

V úvode sa pokúsime o vymedzenie ekologickej etiky - ako subdisciplíny aplikovanej etiky. Ekologická etika je spôsob aplikácie normatívnej etiky na určitý súbor praktických (problémových) otázok, ale zároveň predstavuje aj nový spôsob realizácie rozširujúceho spektra konceptov normatívnej etiky vo všeobecnosti. Na rozdiel od ostatných morálnofilozofických prístupov, ekologická etika nepracuje ani retrográdnou (top-down), ani progresívnou (bottom-up) metódou, ale považuje teóriu za nevyhnutnú pre úspešnú prax a prax za nepostrádatel'nú pre vytvorenie relevantnej teórie. Ekologická etika je tak normatívna ako aj aplikovaná; na jednej strane vyplýva z normativity a praxe - no na strane druhej ich formuje (Vladyková 2013). Prísne vzaté: existujú črty alebo zložky, ktoré spoločne charakterizujú a približne definujú ekologicko-etický prístup: 1. jeho dosah je/musí byt́ globálny; 2. je interdisciplinárny; 3 . spája teóriu a prax.

Kritérium "globálneho dosahu" je v ekologickej etike evidentné dvoma spôsobmi: vyžaduje sa globálny rámec a zároveň sa vyžaduje, aby bolo do úvahy brané konanie a povinnosti jednotlivcov, skupín, ale aj inštitúcií. Ak sa má ekologická etika zaoberat́ dilemami v súčasnom svete, potrebuje pochopit' aktérov, ktorých študuje. To vyžaduje viac než len morálnu a ekologicko-filozofickú analýzu. Je potrebná expertíza celého spektra odborníkov: ekonómov, právnikov, ekologických špecialistov a sociológov, ale aj odborníkov z praxe, aktivistov a zákonodarcov. Ak chceme brat́ ekologický dosah etiky vážne, tak je potreba interdisciplinárnej ${ }^{1}$ expertízy zrejmá. $Z$ toho vyplýva, že ekologická etika je vo

\footnotetext{
${ }^{1} \vee$ literatúre sa dnes používa aj neutrálny termín cross-transdisciplinarity, ktorý odkazuje na „prekríženie" disciplín v spoločenských, humanitných a prírodných vedách (predpokladá rovnaké východiská a podmienky ako interdisciplinárny, multidisciplinárny a medziodborový výskum). Pozri: Lowe, P., Whitman, G., \& Phillipson, J. (2009). Ecology and the social sciences. Journal of Applied Ecology, 46(2), 297-305, DOI: 10.1111/j.1365-2664. Rozdiely medzi trans - multi- a inter-disciplinarnym výskumom uvádzame $v$ tabulke:
} 
svojej podstate interdisciplinárna. Ekologická etika sa dotýka fundamentálnych problémov skutočného sveta, skutočnej nespravodlivosti, ludského a mimoludského utrpenia a globálnych hrozieb, takže nemôže byt́ chápaná iba ako intelektuálne cvičenie.

\section{Náčrt morálnej filozofie akcentujúcej úvahy ekologického typu - ekologická etika}

V roku 1991 John Brockman (editor zborníka Príštích padesát let. Věda v první polovině 21. století. 2004; Třetí kultura. 2008) uverejnil štúdiu Tretia kultúra, kde uvažoval o novom type kultúry reprezentovanej vedcami a myslitel'mi empirického sveta, ktorí zviditelňujú hlbší význam našich životov a poskytujú nový pohlad na to, kým a čím vlastne sme. To, čo sa tradične nazývalo vedou, sa dnes stáva "verejnou kulturou". Autor sa domnieva, že „...lúludská povaha sa príliš nemení, ale veda áno a táto zmena narastá a nezvratne mení svet... veda sa teda stáva velkým príbehom" (Brockman, 2008: 8). Vedci v oblasti prírodných a technických vied hovoria jazykom, ktorému porozumejú aj ich kolegovia v iných disciplínach. "Myslitelia tretej kultúry sú noví verejní intelektuáli" (ibid., 2008: 9). Ich ciel'om je určit́ aktuálny stav vedeckého výskumu, zrozumitel'ný nielen $\checkmark$ rámci vedeckej obce, ale aj pre široké publikum. Možno najdôležitejšou úlohou tretej kultúry je dôraz na to aby sa „...všetci vyjadrovali o tej istej veci, o tomto kváziobjekte ${ }^{2}$, ktorý sme vytvorili, o tomto objekte-diskurze-prírode-spoločnosti, ktorého nové vlastnosti nás všetkých udivujú a ktorého siet́ sa šíri...prechádzajúc chémiou, právom, štátom, ekonómiou a satelitmi" (Latour, 2003: 189).

V tejto súvislosti vyvstáva pred nami otázka, akú rolu pri „zviditelñovaní ... a vyjadrovaní o tej istej veci" zohráva morálno-filozofická reflexia, $v$ tomto prípade morálnofilozofická reflexia ekologického problému, kde odpoved' na to, aké je naše miesto a úloha "V súbore praxí", vo vztahoch "prírody - kultúry", kým a čím vlastne sme, je dôležitá. Opodstatnené výhrady, že z ekologickej vedy nemôžeme bezprostredne vyvodit' metafyzické, epistemologické, axiologické a etické závery, vedú mnohých vedcov k reflexiám totožným s názorom S. Weinberga (nositel' Nobelovej ceny za fyziku), že pre prírodovedcov je vývoj filozofie nepodstatný. Weinberg tvrdí, že s podozrením sleduje všetky pokusy od Aristotelovej doby vybudovat' morálno-filozofický alebo estetický systém a „...ešte s väčším podozrením pokusy niečo o týchto veciach dokázat" (Weinberg, 2004: 49). Zdá sa, že z pozície filozofie sa súčasná veda nedočká návodov, ako bádat́ a čo vybádat'. S. Weinberg však pripomína, že ani vo vede „... neexistuje žiadna jasná a univerzálna vedecká metóda a všetky pokusy ju sformulovat', od čias Francisa Bacona, nedokázali zachytit' to, ako veda

\begin{tabular}{|c|c|c|}
\hline Transdisciplinárny výskum & Multidisciplinárny výskum & Interdisciplinárny výskum \\
\hline $\begin{array}{l}\text { Spolupráca, v ktorej ide o výmenu in- } \\
\text { formácií, o spoločné špecifické prístupy, } \\
\text { zdiel'anie zdrojov a integráciu odborov, } \\
\text { kde sa dosahuje spoločný vedecký ciel'. } \\
\text { Transdisciplinárny výskum umožňuje } \\
\text { bádatelom "prekračovat' priestor" svojej } \\
\text { vlastnej disciplíny, vzájomne sa informo- } \\
\text { vat', zachytit' zložitost' výskumného pro- } \\
\text { blému a vytvorit' nové intelektuálne } \\
\text { priestory. }\end{array}$ & $\begin{array}{l}\text { Výskumní pracovníci } \\
\text { z rôznych odborov pra- } \\
\text { cujú spoločne v určitom } \\
\text { okamihu v priebehu pro- } \\
\text { jektu, ale majú samo- } \\
\text { statné otázky, samostat- } \\
\text { né závery. }\end{array}$ & $\begin{array}{l}\text { Vedci komunikujú s ciel'om } \\
\text { prenosu poznatkov z jednej } \\
\text { disciplíny na druhú. Umož- } \\
\text { ňuje vedcom vzájomne sa } \\
\text { informovat' o svojej práci } \\
\text { a kontextuálne porovnávat' } \\
\text { jednotlivé výsledky výsku- } \\
\text { mu. }\end{array}$ \\
\hline
\end{tabular}

2 Podl'a B. Latoura kváziobjekty sa nám prezentujú „raz ako vec, raz ako rozprávanie, raz ako sociálne puto, no nikdy sa pritom neredukujú na jednoduché súcno... O kváziobjektoch ... jednoducho povieme, že tvoria siete. Sú reálne, ...pritom diskurzívne, naratívne, historické, vášnivé a zaplnené aktantmi autonómnych foriem" (Latour, 2003: 117-118). 
a vedci v skutočnosti pracujú" (ibid. 49). Dodajme, že vel'a z toho, k čomu môžeme dospiet́ na základe vedeckých analýz, je nevyhnutne predbežné.

Zároveň nemáme k dispozícii ani vo vede ani vo filozofii „ideálnu teóriu", ktorá by jednoznačne smerovala od metafyzickej, resp. ontologickej doktríny k vedeckému teoretizovaniu, morálnym a politickým zásadám a $\mathrm{k}$ celkovému pohl'adu na svet, $\mathrm{v}$ ktorom miesto človeka a význam ludského života sú jasne stanovené. Pokial' vo filozofii a etike nechceme prešlapovat' na mieste, nie je žiaduce iba trpezlivo čakat́ na ideálne teórie ekológických vied. Pasívna úloha pre filozofov nie je ani nutná ani želatelná. Ekologické vedy ako skutočne architektonické vedy, resp. vedy syntézy sužujú rôzne rozkoly, tiahnuce sa pozdíž ich subdisciplinárnych, metodologických a filozofických hraníc. Napriek tomu, či práve preto, tu existuje velký priestor pre skúmanie. Nepochybne $v$ tejto oblasti môže praktická filozofia profitovat' z dôslednej koncepčnej kritiky a analýzy druhého rádu, kde je úloha filozofie a etiky nezastupitel'ná. Ako navrhuje K. deLaplante (2004), v tomto význame prínos filozofie a etiky pre rozvoj ekologickej vedy a pre ich vzájomné vztahy môže zahŕňat́:

- rozpracovanie argumentov pre a proti rôznym interpretáciám ekologickej teórie

- skúmanie stratégií podpory produktívneho dialógu medzi inak izolovanými ekologickými subdisciplínami

- skúmanie úlohy individuálnych a spoločenských hodnôt $v$ praxi ekologickej vedy a pri rozvoji a posudzovaní ekologických teórií.

V súvislosti s identifikáciou ekologickej etiky, ktorá je uvedená vyššie, z uvedeného vyplýva, že výzvy, ktoré stoja pred projektom ekologickej etiky, sú späté so všeobecnými filozofickými otázkami týkajúcimi sa podstaty ekologickej vedy a ekologického poznania, pretože ide o "zvláštny prípad" vo sfére etiky, prekračujúci rámec čisto medziludských vztáahov, ktorý bol až do nedávna tradičným rámcom etiky. Postihuje vztah človeka k iným živým mimol'udským bytostiam, ba dokonca k neživým prírodninám. Stáva sa pokusom o zviditel'nenie hlbšieho významu života a poskytuje nový pohlad na naše miesto $\checkmark$ prírodnom svete pýtaním sa na to: čo musíme vediet' a ako máme konat's ohladom na ekologický rozmer porozumenia a pochopenia nášho bytia a predovšetkým na to, aký by mal byt' spôsob života, o ktorý by sme sa mali usilovat'. Pýta sa na svet, $v$ akom by sme mali a chceli žit' (aspoň $v$ tom zmysle, že toto pýtanie spustí d’alšie evolučné napredovanie nášho morálneho vedomia odmietaním „....násilných vzt́ahov, ktoré sme udržiavali s inými prírodami-kultúrami" (Latour, 2003: 24). Je pýtaním sa a premýšl'aním o hodnotách l'udského života, o hodnotách mimoludského života a o hodnotách života vôbec. V teoretickej rovine je spôsobom aplikácie normatívnej etiky na určitý súbor praktických (problémových) otázok, ale predstavuje nový spôsob zdôvodňovania a aplikácie vo všeobecnosti. ${ }^{3}$ Už

\footnotetext{
${ }^{3}$ Arthur Rich (1994) zarad'uje k hlavným podobám normatívnej etiky okrem etiky noriem a princípov, kazuistickej etiky, situačnej etiky, etiky zmýšlania a etiky zodpovednosti aj empirickú etiku (empirické zdôvodňovanie morálky), ktorá je bežne súčast́ou deskriptívnej etiky. Zdôvodňuje to tým, že nad čistú opisnost' sa empirická etika dostáva povyšovaním empiricky opísatel'ného a overitel'ného pravidla správania na hodnotu povinnosti a udeluje mu normatívnu váhu. Ide o tzv. normativitu faktického. Preniest' normativitu faktického do ekologickej etiky je súčast́ou našej analýzy vzt́ahu vedy a etiky a následne pochopenia prírody ako existenčného habitatu človeka. Kedže štúdium etiky sa obvykle riadi určitými predpokladmi (medzi hlavné patrí: 1. že sme viac menej racionálne bytosti, ktoré dokážu pochopit' svet; 2. môžeme konat' na základe toho, čo pochopíme; 3. naše konanie môže slúžit' účelu, ked' človek ako rozumná bytost', ktorá je schopná konat' na základe pochopenia), deskriptívne výroky o tom, čo je (príroda je ohrozený existenčný habitat človeka), zamieňa za normatívne výroky (kedže sledujeme svoj životný záujem, sledujeme záujem prírody), vstupujú do hry "skryté" hodnotové po-
} 
nejde len o zdôvodňovanie prostredníctvom určitého teoretického princípu, resp. konceptu na konkrétnu problémovú oblast', ale kontext konkrétnej problémovej oblasti, situácie, prípadu je ( $v$ prípade potreby) priestorom teoretického odvodzovania. Nový spôsob zdôvodňovania a aplikácie pramení z evidencie dynamického rozvoja vedy, vedeckého poznania a techniky a ich vplyvov, resp. transformačných zmen sveta prírody i kultúry. Aj ked' ekologická etika je $v$ konečnom dôsledku teoretickou výpoved'ou, zhromažd'ovanie racionálnych podnetov, poznatkov a empirických štúdií, resp. relevantných faktov (praktický logos) ${ }^{4}$ umožní konat́ na základe kata ton orthon logon (podl'a správneho úsudku) ${ }^{5}$ $v$ slede udalostí, na ktoré nemáme k dispozícii žiadne morálne záväzné pravidlá. Je to vyjadrenie úsilia odhalit́ väzby, architektúru a možnú zranitel'nost́ sociálnych sietí životného sveta, odhalit' sietovitú štruktúru navzájom spojených úrovní biosféry atd'.

H.-G. Gadamerom vyslovená myšlienka oceňujúca praktickú filozofiu rozpracovanú Aristotelom, a to nielen $v$ tom, čo má platit za správne, ale predovšetkým $v$ tom, že za centrálnu úlohu filozofickej etiky i mravného správania označil konkretizáciu všeobecného a aplikáciu na danú situáciu, tu má zásadnú opodstatnenost', lebo „.... teoretické výpovede o praktickom dobre....sú získané z odboru praktickej skúsenosti" resp. sa nakoniec vztáhujú k praxi ako ku svojej predbežnej podmienke (Gadamer 1994: 105).

Ekologická etika je východiskom produktívneho úsilia porozumiet́ tomu, ako reálny svet skutočne funguje. Jej cesta a smerovanie je $v$ porozumení úžasnej komplexity tak životného ako aj prírodného sveta, $v$ porozumení tomu, čo je $v$ centre pozornosti vedcov a etikov. Toto porozumenie je možné za predpokladu "obnovy dôrazu na interdisciplinárny výskum v renesančnom štýle" $v$ štýle ekologickej synergie, resp. komplementarity „....prieniku vedy do psychosveta a sociosveta" (Kováč, 2000: 98). Na tejto pôde, vo svojom pragmatickom užití, sa stretáva racionalita a moralita.

Natíska sa však d'alšia otázka: ako presadit́ požadovaný diskurz, ked' vieme, že etika pôsobí ako výzva (ale aj ako narušenie) pre organizujúce princípy vedy, resp. vedu všeobecne? Ked' vieme o napätí spočívajúcom $v$ inherentnej konfrontácii poznania a hodnotenia, $v$ spore o zdroje hodnôt a morálky, $v$ spore, či sú veda a filozofia schopné sprostredkovat' legitímne vedenie, $v$ situácii ked' „...fakty sú neisté, hodnoty sporné, riziko vysoké a rozhodnutia naliehavé" (Funtowicz - Ravetz 1992: 254).

Predbežná poznámka: na jednej strane intuitívne cítime, že vzdialenost́ medzi obrazom sveta vytváraného vedeckými teóriami (teda tým, čo je) a medzi morálkou, zodpovednostó a dôstojnost́ou jednotlivca (tým, čo by malo byt') je taká velká, že ludstvo si zrejme skôr poradí s vedeckými (tzn. technickými a prírodovednými) problémami, ako s morálnymi a etickými, tzn. skôr si poradí s vlastnou racionálnou kreativitou zameranou na poznanie prírody, ako so spôsobmi obývania prírodného sveta. Druhou stranou tohto tvrdenia je, že bez ohladu na to, čo nám vedci hovoria, sa veda stala neobmedzeným hladaním zmys/u. Vedecké teórie vytvárajú obrazy sveta, ktoré systematizujú, predvídajú a sú schopné podávat' vysvetlenie.

stoje "a práve v tomto zmysle sa empirická etika javí ako skrytá odnož normatívnej etiky" (Rich, 1994: 27). Produktívnou sa nám zdá interpretácia normatívnej etiky ako sféry zameranej na hladanie „....konania, ktoré je správne za špecifických, konkrétnych okolností” (McGinn, C. 2001. Das Gute, das Bose und das Schone. Stuttgart: Klett-Cotta: 15).

${ }^{4}$ Nemáme na mysli užívanie tohto pojmu v reči ako prostriedku komunikácie, ale skôr jazyka ako určitého zdroja zmyslu, ktorý je pre R. Rortyho (Prostor, 1994: 107-116) implicitne pluralitný, tzn. nie je to jeden jazyk, ale mnoho vzájomne sa podmieňujúcich jazykov.

${ }^{5}$ Aristoteles: Etika Nikomachova. 1138b25. 
Na rozdiel od iných l'udských aktivít si veda nekladie za ciel' svet menit', ale menit' predstavu o ňom, čo však znamená vážnu konzekvenciu, lebo tak ako si svet predstavujeme - tak v ňom konáme. Hladanie zmyslu veda spája so schopnost́ou vysvetlovat' tak, že používa repertoár myšlienok prírodnej a morálnej filozofie v rozmanitosti a bohatstve, ktoré sa dosiahlo v histórii myslenia (napr. ekológia sa len tažko môže zaobíst́ bez normatívnych úsudkov o tom, čo je v súcne významné, prečo a čo je dôležité pre život; v tejto súvislosti vstupuje na pole filozofie a deklaruje potrebu vzájomnej interakcie). Jednoducho: vo svete kde vládne veda, kde sa s vedou radíme, musí človek overovat významy, ktoré nám predkladá veda a jej teórie, lebo majú dopad na kvalitu nášho najintímnejšieho každodenného života.

Vychádzajúc z predpokladu nenahraditel'nosti prírody ako existenčného habitatu l'udského i mimoludského (rozumej: materiálna a ekologická oporná základňa, resp. iné nezávislé bytie od ktorého sme závislí - jeho ontologický status vytvára axiologický predpoklad pre etický rozmer), polarizácie, konštrukcie tzv. párových opozít, centrizmy a následne normatívne univerzalizácie, či už l'udského alebo mimoludského, ktoré sú nad’alej prítomné v diskurze danej problematiky - sa javia ako neproduktívne. Sú však následkami západného racionalistického hyperoddelenia l'udskej identity od prírody a panskej, resp. hegemonistickej pilotáže. V predloženom texte uvažujeme o možnom oslabení tak pojmovej redukcie, ako aj zmienenej hyperseparácie od prírody - vo vízii ekologickej synergie (Wenz, 2001), ktorej fundament možno zhrnút takto: (re)situovanie ludí z ekologického hladiska (je zjavne naliehavé a je to úloha prezieravosti, súvisiaca s poznaním prírodného sveta) a (re)situovanie mimoludského z etického hladiska (úloha etiky, súvisiaca s obývaním a hodnotením prírodného sveta). Obe úlohy sú synergicky prepojené a nie je možné ich zvládnut́ izolovane.

V našom dlhodobom skúmaní (Vladyková, 2004, 2009, 2013, 2015) sme sledovali a nad'alej sledujeme cestu umiernenosti a zdržanlivosti voči bezbrehému entuziazmu i kategorickému odmietaniu moderného, resp. ne-moderného, pred-moderného, postmoderného atd'. projektu rozumu, kultúry, prírody a techniky. Jedným z prvých krokov tejto umiernenosti je, že identifikujeme škálu hodnotových a morálnych kritérií: aké sú, aké nie sú a aké by mali byt́ ( $v$ súvislosti so zaujímaním stanovísk k dôležitým otázkam proprírodne akceptovatel'ného štandardu "dobrého života"). Naliehavé volania domáhajúce sa vhodnej (biofilnej) techniky, hodnotiacej vedy, práv zvierat, inherentnej hodnoty prírody a mimoludských entít, environmentálnych aktivít atd'. znejú nepresvedčivo, ked' sa skízava z dichotómneho modelu rozum/príroda k iným dichotómnym modelom (napr. príroda/rozum). Ako upozorňuje I. Dowbiggin (2002), ani tzv. multikulturálne projekty oslavujúce regióny sveta, kde je bežné bezprávie, mrzačenie žien, kmeňové masakre a náboženské násilie, a feministické definovanie judaizmu ako zločinu voči ženám kvôli patriarchálnemu tónu Starého zákona, nestavajú západný priemyselno-informačný svet kultúry, pýšiaci sa vedou a technikou, do príliš zlého svetla, pretože len sotva má monopol na nemorálnost́ a nespravodlivost'.

V tejto súvislosti je aktuálnym projekt ekologickej synergie, ktorý konštruujeme na báze metateoretického pluralizmu. ${ }^{6}$ Metateoretický pluralizmus zahŕňa otvorenost' voči

\footnotetext{
${ }^{6} \mathrm{Na}$ tomto mieste je potrebné zdôraznit́ pozornost́ venovanú multicentrizmu. Ako sa domnieva A. Weston, oproti holizmu, multicentrizmus netrvá na jednom ekologickom „celku", ktorý je istým spôsobom jediným primárnym etickým centrom. Multiverzum je zmiešanejšie a komplexne štuktúrované, zahŕňajúce aj ekologické "celky" a indivíduá rôzneho druhu a úrovne - druhy, organizmy, biotické komunity - všetky v neustálej zmene a pohybe a žiadne nie sú vždy alebo nevyhnutne primárne. Skutočná práca rozhodovania je skôr aktom balancovania. Multicentrizmus navrhuje odlišný druh
} 
pravdepodobnosti divergentných etických teórií spolupracujúcich na spoločnom morálnom projekte - napr. ekofeministi a ekologickí holisti môžu spolupracovat' v záujme zachovania rovnakých prírodných habitatov na odlišných východiskových nárokoch motivujúcich ich konanie. Dôležitou sa javí otázka, či metateoretický pluralizmus naviguje teoretické reflexie $\mathrm{k}$ určitému druhu postmoderného relativizmu. Rôzne výklady ekologického pragmatizmu (Light, Katz, 1996) však naznačujú, že tomu tak nie je.

Reálna skúsenost́ nie je unicentrická - inak povedané: ocenenie subjektívnej povahy skúsenosti prináša so sebou nevyhnutnost' epistemologickej pokory k životom iných a k tomu, čo možno označit ako správne (vyhovujúce) pre nich. S touto myšlienkou (možno nie celkom konzistentne) súvisí reflektovanie morálnej významnosti „vzácneho prírodného bytia" (Šmajs 1995). Zohladnenie morálnej významnosti je tu na mieste, pretože ak si niečo vyžaduje, aby sme to brali do úvahy pri našich morálnych hodnoteniach a súdoch, tak to morálne významné je. Morálna významnost́ je jedným z determinantov prechodu od jednej etiky $k$ inej, pokial' sa preukáže, že existujú nové morálne relevantné znaky, ktoré sú ignorované $v$ konzervatívnejšej etike. Pokial' v ekologickej etike identifikujeme znaky morálnej významnosti, prihliadame bud' na antropocentrické východiská7 alebo na neantropocentrické východiská. ${ }^{8}$ Uplatňujeme holistické preferencie ${ }^{9}$ alebo individualistické preferencie (pozornost' sa sústred'uje na predpoklad priority jednotlivcov, napríklad zvierat u P. Singera, T. Regana a i.). Už tento náčrt "centristicky navigovaných" argumentácií mo-

rozhodovania: procedurálny model založený na dialógu s otvoreným koncom a rokovaniach. $V$ tejto súvislosti je zaujímavou požiadavka acentrizmu S. Batchelora (1994).

${ }^{7}$ Formulujú sa v rôznych podobách; bud' je to radikálna verzia antropocentrického karteziánstva (silná verzia antropocentrizmu), alebo sú to umiernené (slabé) verzie; v scenároch tzv. silného antropocentrizmu sa príroda nad’alej interpretuje len ako objekt, čo implikuje vydelenost́ človeka z prírody; tzv. umiernené (slabé) verzie antropocentrizmu možno dokumentovat slabým antropocentrizmom B. Nortona (1984) alebo kultivovaným antropocentrizmom (tiež metodologický antropocentrizmus) K. Otta (1993), kotviacim v tradícii nemeckej klasickej filozofie a fenomenológie, zohl'adňujúcim dlhodobejšie časové horizonty záujmov človeka a rozširujúci morálne správanie na tzv. moral patiens (bytosti, ktoré sa nemôžu vo vzt́ahu k človeku chovat́ morálne recipročne); J. Habermas (1991) interpretuje l'udský vzt́ah k mimoluudským bytostiam na základe morálnej významnosti v kantovskej tradícii a navrhuje rozšírenie anamnetickej solidarity (súcitnej solidarity) na mimoludskú prírodu; M. Seel (1991) v estetike prírody, rozlišovaním troch základných foriem estetického vztáahu k prírode, ktoré interpretuje ako kontempláciu, koreláciu a imagináciu, dostáva k tvrdeniu, že len filozofické objasnenie estetického rozmeru prírody poskytne návod na "dobrú etiku životného prostredia"; L. Ferry (1992) uvažuje o perspektívnom antropocentrizme vo význame rozšírenia referenčnej roviny morálnych súdov na oblast' prírody; ap. $V$ tomto type koncepcií dochádza k novému nazeraniu na vztáah poznania a hodnotenia, racionality, emocionality, morálky a etiky.

${ }^{8}$ Neantropocentricky, kozmocentricky, biocentricky, naturcentricky, ekocentricky orientované prístupy v ekologickej etike ponímajú prírodu (kozmos, biosféru, ekosféru, jednotlivcov mimol'udských druhov) ako hodnotu samu o sebe a ludské hodnotenie sa stáva reálnym len vo vztahu k týmto sféram; ide o posun tažiska vlastnej hodnoty z l'udských jednotlivcov na mimol'udských jednotlivcov a entity, biosféru alebo ekosféru.

${ }^{9}$ Holistické preferencie možno interpretovat' paradigmaticky, tzn. všetko existuje vo vztáahu k všetkému ostatnému: táto paradigma sa vyznačuje jemnejším „zmyslom pre oddel'ovanie"; tradičné dualizácie sa reinterpretujú v tom zmysle, že predstavujú rôznorodost' a inakost'; medzi holistickými alternatívami existuje určitá rozmanitost' (čo je jednou z príčin, prečo nemožno hovorit́ o jedinom ekologickom svetonázore), tzv. "silný holizmus" prezentuje fenomény, entity a bytosti participujúce na jedinej ontologickej báze (hlbšej realite), ktorá sa často interpretuje a posudzuje mystickým jazykom; tzv. "slabý holizmus" usúvztažňuje fenomény v spoločnom počiatku a intrinzickej prepojenosti do funkčnej siete bez toho, aby sa predpokladal nejaký hlbší zjednocujúci princíp; tak silný ako aj slabý holizmus môže byt' bud' hierarchický alebo egalitársky - pozri: A. Leopold (1999), J. B. Callicott (1989), F. Capra (1992), R. Sheldrake (2002), P. Shepard (1969), H. Rolston III. (1988, 1989), a i. 
rálnej významnosti, nám približuje mnoho tém naznačujúcich diverzitu, resp. expanziu centier, ktorými sa zaoberala a zaoberá alternatívna ekologická filozofia a etika od svojich počiatkov.

Velká čast' súčasnej ekologickej etiky je založená na presvedčení, že blaho l'udských a mimol'udských bytostí $v$ dobe antropocénu ${ }^{10}$ je ohrozené narastajúcim ekologickým problémom spôsobeným činnostou človeka - znečistenie životného prostredia, nadmerný nárast populácie, spotreba neobnovitel'ných prírodných zdrojov, devastácia existenčného habitatu a strata biodiverzity, ozónová diera, skleníkový efekt atd'. Empirické vymedzenie ekologického problému je jasné a zrozumitel'né a jednoznačne potvrdzuje zmysluplnost' a relevanciu vyššie artikulovanej teoretickej navigácie ekologickej etiky.

\section{Literatúra}

- Batchelor, S. (1994). Alone with Others: An Existential Approach to Buddhism. New York: Grove Press.

- Batchelor, S. (1994) Reinterpretace budhistické ekonomiky. In Dharma Gaia. Eseje o budhizmu a ekológii. Bratislava: CAD Press.

- Brockman, J. (2008). Třetí kultura. Za hranice vědecké revoluce. Academia: Praha.

- Callicott, J. B. (1989). In Defense of Land Ethic. Essays in Environmental Philosophy. New York: University of New York Press.

- Capra, F. (1992). Tao fyziky. Bratislava: Gardenia Pragma.

- Dowbiggin, I. (2002). "A Rational Coalition": Euthanasia, Eugenics, and Birth Control in America, 1940-1970. JPH, 14(03), 223-260. Retrieved from http://www.journals.cambridge.org/abstract_S0898030600000269 http://dx.doi.org/10.1353/jph.2002.0017

- Ferry, L. (1992). Le nouvel ordre écologique; I'arbre, I'animal et I'homme. Paris: Grasset.

- Funtowicz, S. O., \& Ravetz, J. R. (1992) Three Types of Risk Assessment and Emergence of Post-Normal Science. In S. Krimsky \& D. Golding (Eds.), Social Theories of Risk (pp. 251-273). Connecticut: Praeger.

- Gadamer, H. G. (1994). Idea Dobra mezi Platónem a Aristotelem. Praha: Oikúmené.

- Kováč, L. (2000) Človek je fanatik zmyslu. In Kritika a kontext 2000/1, 98-99. In: Kritika a kontext 2000/1, 98-99.

- Latour, B. (2003). Nikdy sme neboli moderní. Bratislava: Kalligram.

\footnotetext{
${ }^{10}$ Hovoríme o ANTROPOCÉNE - období, ked' ludstvo svojou činnostou globálne ovplyvňuje zemský ekosystém. Najvýraznejším rysom antropocénu je, že to je prvá geologická epocha, kde si je určujúca sila (to sme my) aktívne vedomá svojej úlohy. Takže antropocén začína, ked'sa lúdia stanú vedomí svojej globálnej úlohy pri formovaní klúčových častí systému Zeme - a ked’ toto vedomie utvára vztáah s prírodným prostredím.
} 
- Leopold, A. (1999). Obrázky z chatrče. Abies: Tulčík.

- de Laplante, K. (2004). Environmental Alchemy. Environmental Ethics, 26(4), 361380. Retrieved from http://www.pdcnet.org/oom/service?url ver=Z39.882004\&rft val $\mathrm{fmt}=$ \& rft.imuse id=enviroethics $2004 \quad 0026 \quad 0004 \quad 0361 \_0380 \&$ \&ve id=info: $w$ ww.pdenet.org/collection http://dx.doi.org/10.5840/enviroethics20042643

- Light, A., Katz, E., (1996). Environmental Pragmatism. New York: Routledge: London.

- Habermas, J. (1991). Erläuterungen zur Discursethik. Frankfurt am Main: Suhrkamp.

- Harding, S., \& Harding, S. (2000). Decentering the Center. Philosophy for a Multicultural, Postcolonial, and Feminist World. : Indiana University Press.

- Norton, B. G. (1984). Environmental Ethics and Weak Anthropocentrism. Environmental Ethics, 6(2), 131-148. Retrieved from http://www.pdcnet.org/oom/service?url ver=Z39.882004\&rft_val_fmt=\&rft.imuse_id=enviroethics_1984_0006_0002_0131_0148\&svc id=info: $w$ ww.pdcnet.org/collection http://dx.doi.org/10.5840/enviroethics19846233

- Otto, K. (1993). Ökologie und Ethik. Tübingen: Attempto Verlag.

- Rolston, H. (1988). Environmental Ethics. Duties to and Values in the Natural World. Philadelphia: Temple University Press.

- Rolston, H. (1989). Philosophy Gone Wild. Buffalo, New York: Prometheus Books.

- Rich, A. (1994). Etika hospodárství I. Praha: OIKOYMENH.

- Seel, M. (1991). Eine Aesthetik der Natur. Frankfurt am Main: Suhrkamp.

- Sheldrake, R. (2002). Teorie morfické rezonance. Nová věda o životě. Praha: Elfa.

- Shepard, P. S. (1969) Ecology and Man: A Viewpoint. In P. Shepard \& D. McKinley (Eds.), The Subversive Science. Boston: Houghton Miffin.

- Šmajs, J. (1995). Ohrožená kultura. Zvláštní vydáni.... Brno: Brno.

- Vladykova, L. (2009). Morálno-filozofické implikácie netradičných ekologických vied $v$ ekofilozofickom diskurze. Acta Facultátis. Košice: Univerzita Pavla Jozefa Šafárika.

- Vladyková, L. (2015). Úvod do filozofie ekológie. Acta Facultátis. Košice: Univerzita Pavla Jozefa Šafárika.

- Vladyková, L. (2013). Etika o vztahu človeka a Zeme. Acta Facultátis. Košice: Univerzita Pavla Jozefa Šafárika.

- Vladyková, L. (2004). Priestor kontextu v proprírodnej etickej reflexii. Filozofia, 59(2), 124-136. 
- Weinberg, S. (2004). Tváŕí v tvár̆. Praha: Aurora.

- Wenz, P. S. (2001). Environmental Ethics Today. New York: Oxford University Press.

- Weston, A. (2004). Multicentrism. Environmental Ethics, 26(1), 25-40. Retrieved from http://www.pdcnet.org/oom/service?url ver $=$ Z39.88-

2004\&rft val fmt=\&rft.imuse id=enviroethics $2004002600010025 \quad 0040 \& s v c$ id=info: www.pdcnet.org/collection

http://dx.doi.org/10.5840/enviroethics200426139 